\author{
優れた高温物性を有する \\ ポリL-乳酸/単層カーボンナノチューブコンポジットの作製 \\ 東京理科大学理学部 澤井大輔・樋口直之・金元哲夫 \\ 京都大学再生医科学研究所 玄丞烋
}

\title{
Enhanced Thermo-Mechanical Properties of Poly(L-lactic acid)/Single-Wall Carbon Nanotube Composites
}

\author{
Daisuke Sawai $^{* 1}$, Naoyuki Higuchi ${ }^{* 1}$, Tetsuo Kanamoto ${ }^{* 1}$, \\ And Suong-Hyu Hyon ${ }^{* 2}$
${ }^{* 1}$ Department of Applied Chemistry, Tokyo University of Science, 12-1 Ichigaya-Funagawara, Shinjuku-ku, Tokyo 162-0826, Japan
${ }^{* 2}$ Institute for Frontier Medical Sciences, Kyoto University, 53 Kawara-cho, Shogoin, Sakyo-ku, Kyoto 606-8507, Japan

\begin{abstract}
The preparation condition of poly(L-lactic acid) (PLLA)/ single-wall carbon nanotube (SWNT) composite films with highly dispersed SWNTs from solutions was examined and the thermo-mechanical properties of the resultant composite films were evaluated by tensile tests, DSC measurements and dynamic mechanical analyses. The dispersion of SWNTs in PLLA/SWNT composites significantly affected by the solvents used and the polymer concentrations. The PLLA/SWNT composite with the highest dispersion of SWNTs was obtained from a $5 \mathrm{wt} \%$ PLLA solution in chloroform. The tensile modulus and strength increased with increasing the SWNT content. The glass transition temperature shifted higher and the heat resistance remarkably improved with increasing the SWNT content. The PLLA/ SWNT composite (PLLA-5) added with $5 \mathrm{wt} \%$ SWNT showed a glass transition temperature of $81^{\circ} \mathrm{C}$ and a storage modulus of $0.91 \mathrm{GPa}$ at $100^{\circ} \mathrm{C}$, which were $14^{\circ} \mathrm{C}$ and 3.3 times higher, respectively, than those pure PLLA film (PLLA$0)$. It is important to note that the rigid-amorphous fraction determined from the DSC thermogram increased with increasing the SWNT content suggesting the specific interaction between PLLA chains and SWNTs. The tensile modulus of 9.2 GPa for a PLLA-5 film drawn to an EDR of 9 was significantly higher than that 7.2 GPa for the PLLA-0 drawn to the maximum achieved EDR of 12. These results indicate that the mixing of small amounts of SWNT $(<5 \mathrm{wt} \%)$ into a PLLA significantly improves the thermal stability and thermo-mechanical properties of PLLA films.
\end{abstract}

(Received 28 August, 2006 ; Accepted 25 October, 2006)

\section{1. 緒 言}

ポリ L-乳酸(PLLA) は再生可能資源を出発原料として合 成される環境循環型生分解性高分子であり，環境に適合 した理想的な材料として注目されている.

これまで我々は主として PLLA の構造と物性に関する 基礎的知見を得ることを目的として, 延伸方法, 延伸条 件, 分子量が PLLAの物性, 構造および結晶転移挙動に あたえる影響を検討してきた[1-4]．また，与えられた一 つの試料内に共存する $\alpha$ 晶と $\beta$ 晶の分率およびそれらの 配向性を DSC, WAXD およびIR を用いて定量的に評価 する方法を報告した[1-3]. さらに, 高分子量ポリ L-乳酸/ ポリD-乳酸ブレンド試料を用いて, 延伸方法や延伸条件
の最適化を行い，ステレオコンプレックス結晶のみから なる試料を作製した。このような試料を評価した結果, それらの延伸試料は $T_{\mathrm{g}}$ 以上での貯蔵弾性率の落ち込みが 小さくなり，耐熱性が純 PLLA 試料より顕著に優れてい ることが分かった[5].

実用材料としてPLLA を扱う場合の課題は, 結晶化速 度が遅いため, 成形加工中に結晶性を高めることが難し く, またガラス転移温度 $\left(T_{\mathrm{g}}\right)$ も $50 \sim 70^{\circ} \mathrm{C}$ と比較的低いこ とである.しかし，これまでにPLLA の成形加工中の結 晶化速度や結晶化度を効果的に高め, 成形加工による実 用レベルの耐熱性を付与した試料作製に成功した例はな い[6-8]. 従って, 成形加工中の結晶性向上を目指して, 結晶核剂を用いた結晶化促進の研究が取り組まれている [9-10]. 
別のアプローチ法としてブレンドによるPLLA 物性改 善の試みがある[11-17]. そのような研究の一つである PLLA/ケナフ複合材料では, PLLA の課題である耐熱性を 大きく改善することに成功し，実用材料として車両，携 帯電話関連の材料として使われている[11-13]. また，ナ ノコンポジットは少量のフィラーを高分子マトリックス に分散させることによって, 顕著な物性の改善を生じ, その程度は分散性に著しく依存することが知られている。 そのため, ポリ乳酸とのナノコンポジットも積極的に行 われている[14-18]. しかしながら現在まで, PLLAナノ コンポジットによって室温における物性は改善している が，耐熱性が顕著に向上したという報告例はない[16-18] カーボンナノチューブ (CNT) は, 代表的なナノフィラー の一つであり, 力学物性に優れ, 耐熱性も極めて高い材 料である. そのため, 高分子に少量の CNT を分散させる ことにより，高分子-CNT 間の相互作用によって, CNT が 有する優れた物性が高分子試料の物性に寄与寸るため, 高分子試料の熱的, 力学的物性の向上が期待できる [19]. また, CNT は高アスペクト比を有するので, ブレンド試 料を一軸延伸によって配向させることにより, CNT も延 伸方向に配向寸れば, さらなる物性の向上が期待できる [19,20]. そこで本研究では, 耐熱性と力学物性の向上を 目指して, 分散状態の良好な PLLA/CNT コンポジットの 作製条件を検討し, ついで作製フィルムおよび延伸物の 物性と構造を評価した。

\section{2. 実 験}

\section{1 試 料}

ポリ乳酸として，三井化学社製ポリ L-乳酸(PLLA, $M_{\mathrm{w}}$ $\left.=2.4 \times 10^{5}\right)$ を用いた. ポリ乳酸は熱や水分, 試料内の残 存触媒, オリゴマーの存在によって, 容易に加水分解が 進行し, 加熱成形に伴う分子量低下が顕著であることが 知られている $[21,22]$. そこで, 残存触媒とオリゴマーを 除去するため, 室温でジクロロメタン溶液に溶解させ, ついで試料をメタノール溶液に再沈殿させた.オリゴマー の除去は IR 測定で確認した. 乾燥後, 分子量低下を抑制 するために, 酸化防止剂として $\boldsymbol{\alpha}$-tocopherol（Vitamin E）
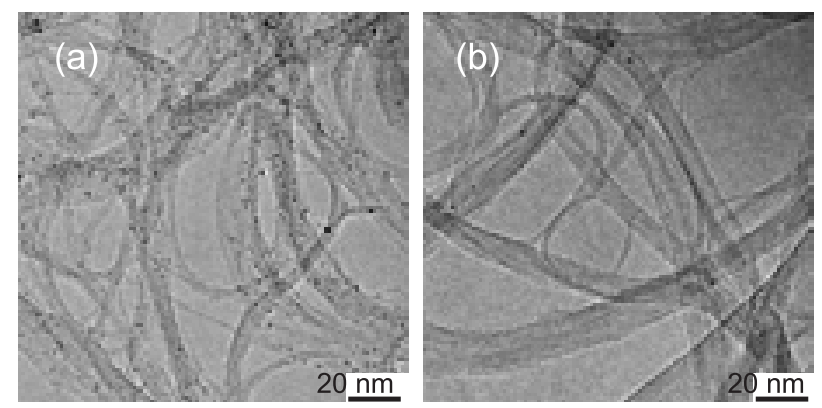

Fig. 1 TEM micrographs of single-wall carbon nanotubes: (a) As-received SWNT and (b) after removal of the catalyst.
をへキサンに溶かし，再沈殿試料とともに覺拌した。へ キサン除去後, $100^{\circ} \mathrm{C}$ で 24 時間減圧乾燥した試料をフィ ルム作製試料として用いた。試料は使用時以外, 減圧乾 燥機中または不活性ガス中で保存した.

ナノチューブとして, CNI 社 (Carbon Nanotechnologies Inc)の HiPco 単層カーボンナノチューブ (SWNT)を用いた. この SWNT は購入段階で約 $10 \mathrm{wt} \%$ の鉄触媒が残存してい るため, 過去の報告例を参照し, 精製を行い純度を高め た試料を実験には用いた[23]. 図 1 に精製前後のSWNT の TEM 写真を示す. 精製前は帯状 SWNT とともに多数 の鉄触媒粒子が観察されたが，精製後は鉄触媒粒子の数 が著しく減少していることが確認できた，そこで，空気 中で TG/DTA 測定を行うことによって, SWNT 内に含ま れる鉄触媒の重量分率を見積もった。本研究では, $800^{\circ} \mathrm{C}$ における残存重量を試料内の鉄触媒分率とした。未精製 SWNT は, $800^{\circ} \mathrm{C}$ において $10 \%$ の重量が残存していたの に対し, 精製 SWNT は約 $1.9 \%$ の重量が残存していた. 以降の実験では精製 SWNT を用いて研究をおこなった。

\section{2 PLLA/SWNT コンポジットフィルムの作製条件}

コンポジットフィルムは溶液からのキャストフィルム 法により作製した. ジクロロメタン, ベンゼン, クロロ ホルムを溶媒として用いて $1 \mathrm{wt} \%$ 10 wt\% PLLA 溶液を 調整し, 室温で一日攪挥した。 その後, PLLAに対し $1 \mathrm{wt}$ $\%$ ～ $\mathrm{wt} \%$ の SWNT を添加し, 超音波処理を 15〜60 分行っ た。混合溶液をガラスシャーレに展開し, 室温で溶媒を 蒸発させた後, $100^{\circ} \mathrm{C}, 24$ 時間減圧乾燥することによって, キャストフィルムを作製した. 物性測定に用いたフィル ムは, SWNT 添加量に応じて, PLLA-1, PLLA-2, PLLA5 と表記する(数字はSWNT の PLLA に対する重量\%). フィルムは使用時以外, 減圧乾燥下で保存した。比較の ために, SWNTを複合しないPLLA キャストフィルム (PLLA-0) も作製した.

\section{3 延伸方法}

延伸には固相共押出延伸 (SSCE) を用いた $[24]$. SSCE は, 以前の PLLA の研究で融点直下での延伸が最も高倍 率まで延伸が可能であったことを踏まえ $[1,2]$, ポリ 4-メ チル-1-ペンテンをビレットとして用い, $T_{\mathrm{e}}=160^{\circ} \mathrm{C}$ の一定 温度で, $1 \mathrm{~cm} / \mathrm{min}$ の押出速度で延伸した. 得られた延伸 試料の倍率は, フィルムに記したインクマークの変位よ り見積もった.

\section{4 構造と物性評価}

\section{4.1 分子量測定 (GPC)}

日本ウォーターズ社製 Waters 2414 をもちいて分子量測 定を行った。 測定温度 $40^{\circ} \mathrm{C}$, 溶媒にクロロホルムを用い た. 分子量は, 単分散ポリスチレンを用いて較正した。

\subsection{2 熱重量分析測定 (TGA / DTA)}

セイコー電子工業社製 TG / DTA220 型熱重量分析装置 
をもちいて熱重量分析 (TG / DTA) 測定を行った。測定は, 乾燥空気雰囲気下で昇温速度 $10^{\circ} \mathrm{C} / \mathrm{min}$ で行った.

\section{4.3 DSC 測定}

融解挙動はセイコー電子工業社製示差走查型熱量計 DSC $220 \mathrm{C}$ を用いて窒素䨌囲気下で昇温速度 $10^{\circ} \mathrm{C} / \mathrm{min}$ で 測定した。融解温度と熱量は, インジウムおよびスズを 用いて較正した。

\section{4.4 粘弾性 (DMA) 測定}

オリエンテック社製粘弾性測定装置 Rheovibron DDVII-EP を用いて, 試料の貯蔵弾性率 $\left(E^{\prime}\right)$, 損失弾性率, $\tan$ $\delta$ を測定した. 測定周波数 $11 \mathrm{~Hz}$, 温度範囲 $-50 \sim 180^{\circ} \mathrm{C}$, H.R. $=2{ }^{\circ} \mathrm{C} / \mathrm{min}$ で測定した.

\section{4.5 TEM 測定}

SWNT からの鉄触媒除去を確認するために, 日立ハイ テクノロジー社製透過型電子顕微鏡 H-9500 を用い, 加速 電圧 $200 \mathrm{kV}$ で観察した.

\section{4.6 光学顕微鏡測定}

オリンパス社製光学顕微鏡 BHSP を用い, キャストフィ ルム内の SWNT 分散状態を定法に従い観察した.

\section{4.7 引張試験}

室温における延伸試料の引張弾性率と引張破断強度は, オリエンテック社製引張試験機 UTM-100 を用いて測定し た。引張弾性率及び破断強度測定時の試料ヒズミ速度は

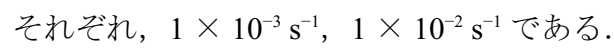

\section{3. 結果と考察}

\section{1 SWNT 分散状態の評価}

SWNT の分散状態が良好な試料において，コンポジッ トによる物性改善は顕著に期待できるため, 溶媒種, 溶 液濃度が PLLA 溶液内での SWNT 分散状態に与える効果 を検討した. PLLA を溶解させるベンゼン, ジクロロメタ ン，クロロホルムを用いて PLLA 濃度の異なる $1 \sim 5 \mathrm{wt} \%$ 溶液を調整した。この溶液中の PLLA にたいして $1 \mathrm{wt} \%$ の SWNTを添加し, 高出力の超音波を照射することによっ て分散溶液を調整し, その後 24 時間放置した。 その結果 を図 2 に示す．全ての溶媒種で, 溶液濃度が高くなると， SWNT の分散状態が良好になることが分かる. 溶媒とし
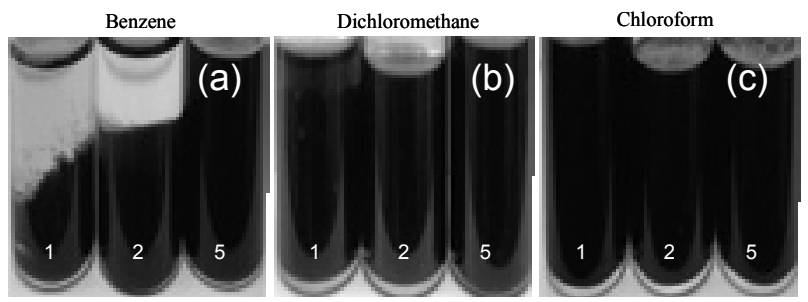

Fig. 2 Visual observations of dispersion states of SWNTs in different solution systems: (a) benzene, (b) dichlorometane and (c) chloroform solutions. The numerals in front of the test tubes show the polymer concentrations.
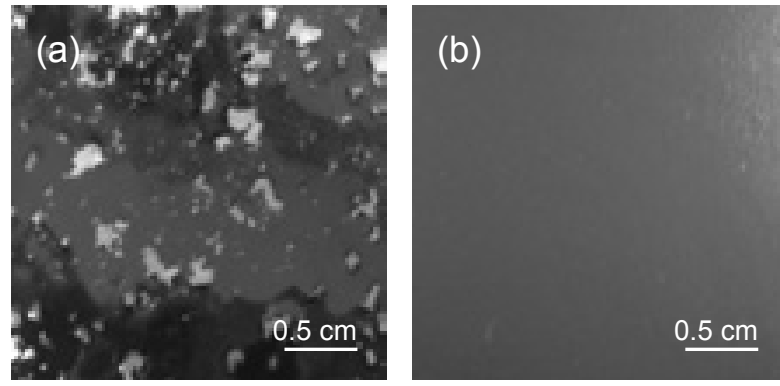

Fig. 3 Visual observations of PLLA/SWNT composites films prepared from (a) a dichloromethane solution and (b) a chloroform solution.

てベンゼンを用いた場合， 1 および 2 wt $\%$ PLLA 溶液は完 全に 2 層に分離した。溶媒としてジクロロメタンを用い た場合も， 1 および $2 \mathrm{wt} \%$ PLLA 溶液は 2 層に分離したが 分離の程度はベンゼンより顕著でなかった。溶媒として クロロホルムを用いた場合, 溶液濃度にかかわらず肉眼 では 1 層であった.

そのため,この時点で 2 層に分離しなかったPLLA/ SWNT 混合溶液をガラスシャーレに展開し，コンポジッ トフィルム作製を試みた。ジクロロメタンおよびベンゼ ン混合溶液から作製したフィルムは，フィルム作製中に SWNT が凝集し, 均一な分散状態を有するフィルムを作 製できなかった。他方，クロロホルム混合溶液からキャ ストすると, 黒色の均一なフィルムが得られた。一例と して，図 3 には $5 \mathrm{wt} \%$ のジクロロメタンおよびクロロホル ム混合溶液から作製した PLLA/SWNT コンポジットフィ ルムの写真を示した.

そこで，目視では均一なコンポジットフィルムが得ら れたクロロホルム混合溶液を用いて, 異なる PLLA 濃度 を持つ溶液から得られたフィルムをマイクロトームで薄 切し, $\mathrm{OM}$ 観察することによって分散状態に与える溶液 濃度の効果を検討した. 2 及び $5 \mathrm{wt} \%$ PLLA 混合溶液から 作製した試料の OM 観察写真を図 4 に示した。 その結果, PLLA 濃度が $2 \mathrm{wt} \%$ 溶液から作製したフィルムは, 目視で は均一な黒色を有するフィルムであったが，OM 観察に よって， $5 \mathrm{wt} \%$ から作製したフィルムと比較して分散のム ラが顕著であることが分かった。すなわち、コンポジッ トフィルム作製時の下部領域(シャーレ底面側)の黒色が
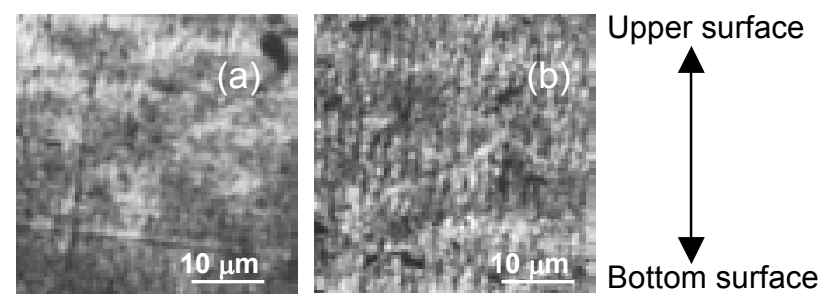

Fig. 4 Photomicrographs of PLLA/SWNT composite films prepared from (a) a $2 \mathrm{wt} \%$ chloroform solution and (b) a $5 \mathrm{wt} \%$ solution in chloroform. 


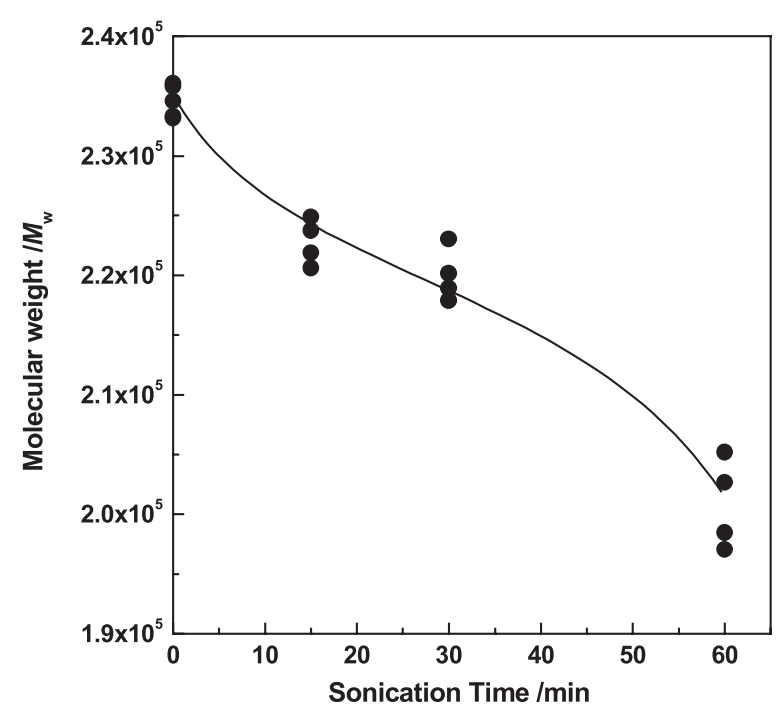

Fig. 5 Effect of sonication time on the weight-average molecular weight of PLLA.

濃く, SWNT がフィルム厚み方向に不均一に分散してい る傾向が観察された。一方， $5 \mathrm{wt} \%$ クロロホルム混合溶液 から作製したフィルムは，そのような上部と下部の不均 一性は見られず，作製したコンポジットフィルムの中で はSWNT が最も良好に分散していた。また，5 wt\%から 作製したフィルムにおいても数 $\mu \mathrm{m}$ 程度の黒色斑点や黒色 のゆらぎが確認されたため，一部の SWNT は分散せず, 凝集していることがわかった。これらの事実は，さらな る SWNT の分散性向上が可能であることを示唆している. しかしながら, 超音波照射による分散では, これ以上の 分散性向上が見られなかったこと, および後述するよう に, これらの作製試料でさえ顕著な物性の変化が生じて いることから，作製した中で最も分散性が良好であった 5 $\mathrm{wt} \%$ クロロホルム混合溶液から作製したフィルムにおい て, SWNTを分散させた効果は充分あると考え, これ以 降の物性検討はおこなわれた。

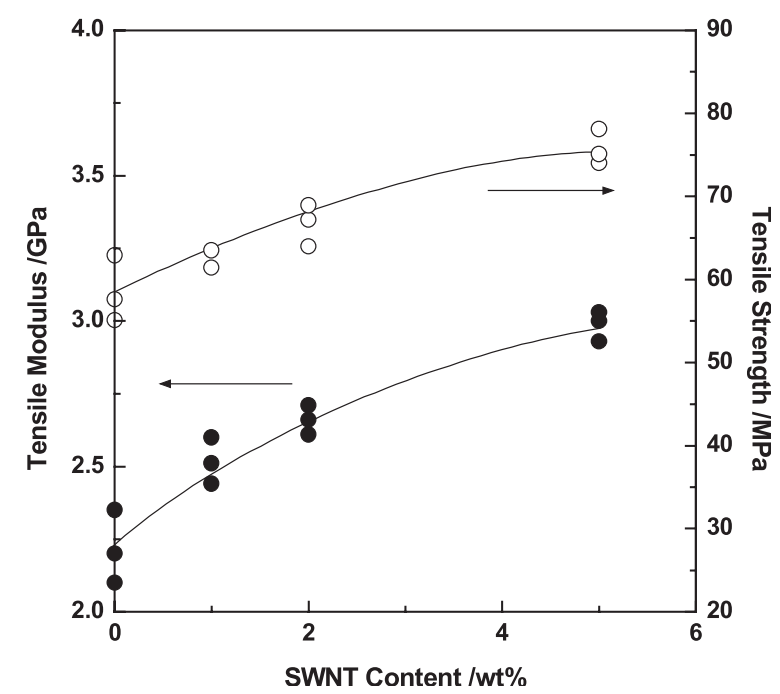

Fig. 6 Tensile modulus and strength of PLLA/SWNT cast films as a function of the SWNT content.

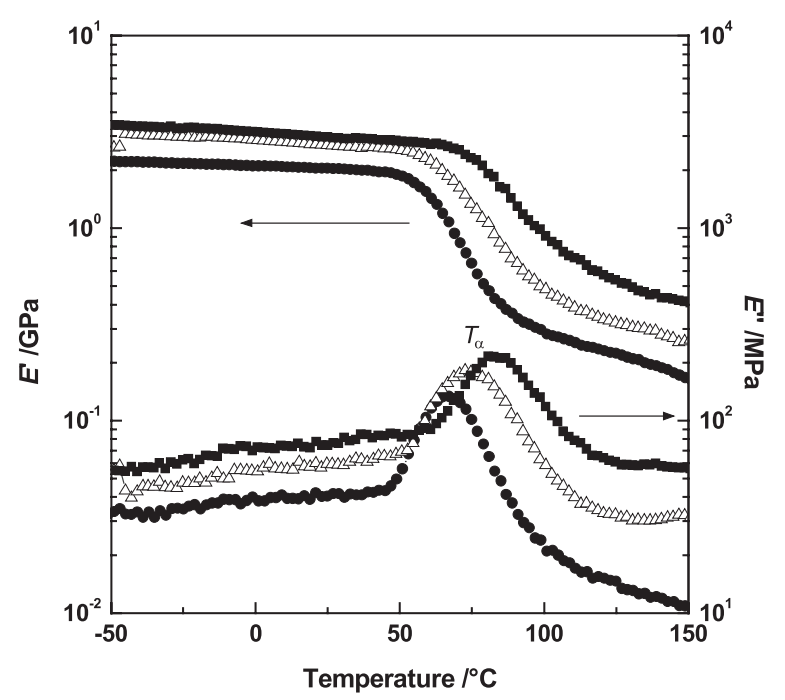

Fig. 7 Dynamic storage modulus ( $\left.E^{\prime}\right)$ and loss modulus ( $E$ ', $)$ vs. temperature for PLLA/ SWNT films, having different SWNT contents, measured at $11 \mathrm{~Hz}$. (○) PLLA-0, $(\triangle)$ PLLA-2, and ( $\boldsymbol{\square})$ PLLA-5.

SWNT を添加したPLLA 溶液に超音波を照射した時間 が SWNT の分散状態に与える影響を検討した。その結果， PLLA/SWNT コンポジットフィルムの分散状態は処理時 間により異なることがわかった. 寸なわち, 15 分の超音 波処理で作製した試料の分散状態はそれ以上超音波処理 した試料よりも分散状態が不良であった。また 30 分以上 超音波処理しても分散状態はほとんど恋化しなかった.

次に, 超音波処理時間が PLLAの分子量に与える効果 を検討するため， $5 \mathrm{wt} \%$ PLLA のクロロホルム溶液を 15 ～ 60 分間超音波処理した後, フィルムを作製し, フィルム の分子量測定を行った(図 5). その結果，試料の分子量は, 超音波処理時間の増加とともに減少した. 以上の結果か ら, 溶媒としてクロロホルムを用いて溶液濃度 $5 \mathrm{wt} \%$, 超 音波処理時間 30 分間の条件で, 分散状態の良好な PLLA/ SWNT コンポジットフィルムを作製できることがわかっ た. また, これ以降の実験ではSWNTの含有量を変化さ せて $(0-5 \mathrm{wt} \%)$ 実験をおこなった。

\section{2 コンポジットフィルムの物性}

PLLA の $5 \mathrm{wt} \%$ クロロホルム溶液に PLLA に対して 0 5 $\mathrm{wt} \%$ の SWNT を添加し作製したコンポジットフィルムを 用いて室温における引張弾性率および引張破断強度を測 定した。図 6 にコンポジットフィルムにおける SWNT 添 加量と引張弾性率および引張破断強度の関係を示した. SWNT 添加量が増加するにつれて, 引張弾性率と引張破 断強度が増加することがわかった. 引張弾性率は PLLA-0 で $2.2 \mathrm{GPa}$ であったのに対し, SWNT 含有量が $5 \mathrm{wt} \%$ のも のは $3.0 \mathrm{GPa}$ となった。 また, 破断強度はポリ乳酸単体で $58 \mathrm{MPa}$ であったのに対し, SWNT 添加量が $5 \mathrm{wt} \%$ もの は $78 \mathrm{MPa}$ となった。このように SWNTを $5 \mathrm{wt} \%$ 添加する ことにより室温における引張弾性率および引張破断強度 
は約 35\% 上昇した。

図 7 にコンポジットフィルムの粘弾性測定の結果を示 した。室温における貯蔵弾性率 $(E ')$ は図 6 の結果と同様 に SWNT 添加量の増加とともに上昇した.さらに，ガラ ス転移に対応する主分散ピーク温度 $\left(T_{\mathrm{a}}\right)$ が SWNT 添加量 の増加とともに顕著に上昇することがわかった， $T_{\mathrm{a}}$ は

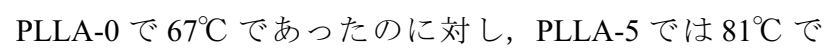
あった。

高分子はガラス転移温度以上で非晶部が軟化するため, PLLA は実用上の耐熱性に難点がある。しかし, 本研究の PLLA/SWNT コンポジットフィルムは SWNT 添加量の増 加とともに $T_{\mathrm{g}}$ (または $T_{\mathrm{a}}$ ) が上昇したため, 高温における

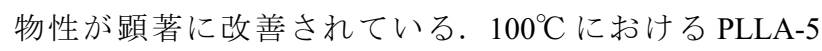
フィルムのE'は, PLLA-0の 3.3 倍に達した。 また, 室温 の $E$ 'に対する $100^{\circ} \mathrm{C}$ の $E$ '保持率は, PLLA-0 試料で $13.3 \%$ であったのに対し，PLLA-5 フィルムは $30.3 \%$ と高温にお ける物性保持率が大きく改善した。このように, 高温に おいて高い物性を保持できるのは, 非晶鎖の状態が異な ることを示している.

図 8 に PLLA-0, PLLA-2 および PLLA-5 フィルムの DSC 曲線を示した。融点および融解熱から算出した結晶化度 はそれぞれ， $168-170^{\circ} \mathrm{C} ， \chi_{\mathrm{c}}=42-44 \mathrm{wt} \%$ となり, SWNT 添 加の有無で変化しなかった (PLLA-0 試料の密度測定によ り求めた結晶化度は $45 \mathrm{wt} \%$ あ゙あ, 融解熱から求めた值 にほぼ一致した)。しかし，図 8 の $T_{\mathrm{g}}$ に対応する比熱の変 化が PLLA-0 試料では $60 \sim 70^{\circ} \mathrm{C}$ に明瞭に観察されるのに 対し, SWNT 添加量が多い試料ほど比熱の変化が高温側 にずれるとともに，比熱変化量が小さくなり，不明瞭に なっていることが分かった. 非晶性 PLLA のガラス転移 における熱容量変化 $\left(\Delta C_{\mathrm{p}}\right)$ は, $0.56 \mathrm{~J} \cdot \mathrm{g}^{-1} \cdot \mathrm{k}^{-1}$ であった のに対し，PLLA-0のガラス転移における $\Delta C_{\mathrm{p}}$ は $0.33 \mathrm{~J} ・$ $\mathrm{g}^{-1} \cdot \mathrm{k}^{-1}$ であり, それらの比 $(0.33 / 0.56)$ を非晶分率とする

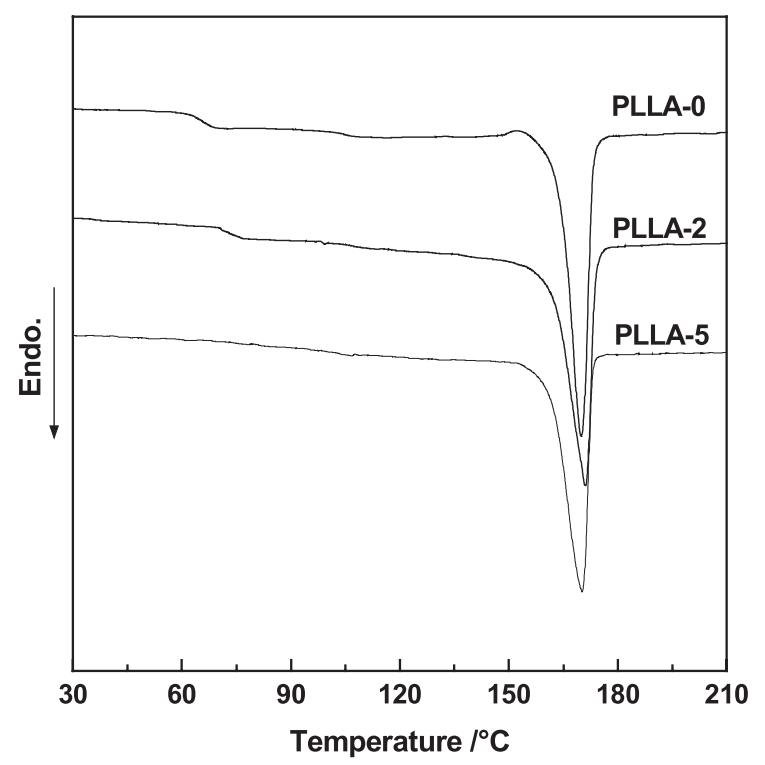

Fig. 8 DSC thermograms for the PLLA/SWNT composite films containing $0 \sim 5 \mathrm{wt} \%$ of SWNT.

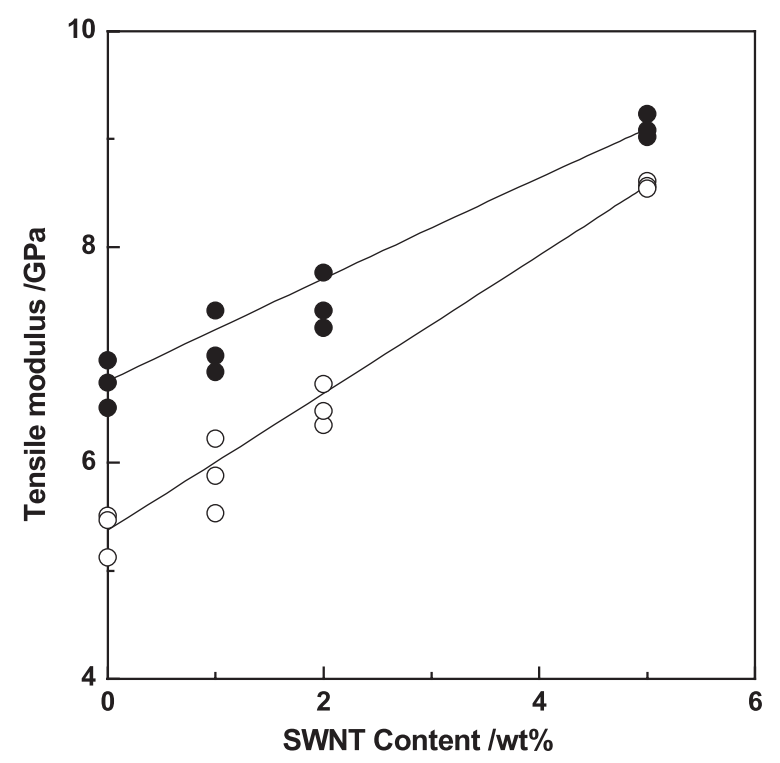

Fig. 9 Tensile modulus vs. SWNT contents of PLLA/ SWNT composite films drawn by solid-state coextrusion at $T_{\mathrm{e}}=160^{\circ} \mathrm{C} ;(\bigcirc) \mathrm{EDR}=6$, $\mathrm{EDR}=9$.

と, 結晶化度 $(41 \mathrm{wt} \%)$ は, 密度および DSC の融解熱量か ら算出した結晶化度 $(42 \sim 45 \mathrm{wt} \%)$ とほぼ一致する。この 結果は, ガラス転移を示さない剛直非晶鎖の存在が複数 の結晶性高分子で明らかにされているが[25-27], PLLA においては，剛直非晶鎖が存在しないと考えて良い[28] ことを意味する.

しかし, PLLA と比べて剛直な SWNTを微分散させる ことにより， $\Delta C_{\mathrm{p}}$ は顕著に低下した(図 8 参照). すなわ ち, PLLA-2 では, $\Delta C_{\mathrm{p}}=0.21 \mathrm{~J} \cdot \mathrm{g}^{-1} \cdot \mathrm{k}^{-1}$, PLLA-5 では $\Delta C_{\mathrm{p}}=0.084 \mathrm{~J} \cdot \mathrm{g}^{-1} \cdot \mathrm{k}^{-1}$ となった. これらのフィルムの DSC の融解熱から求めた結晶化度は SWNT 含量によらず

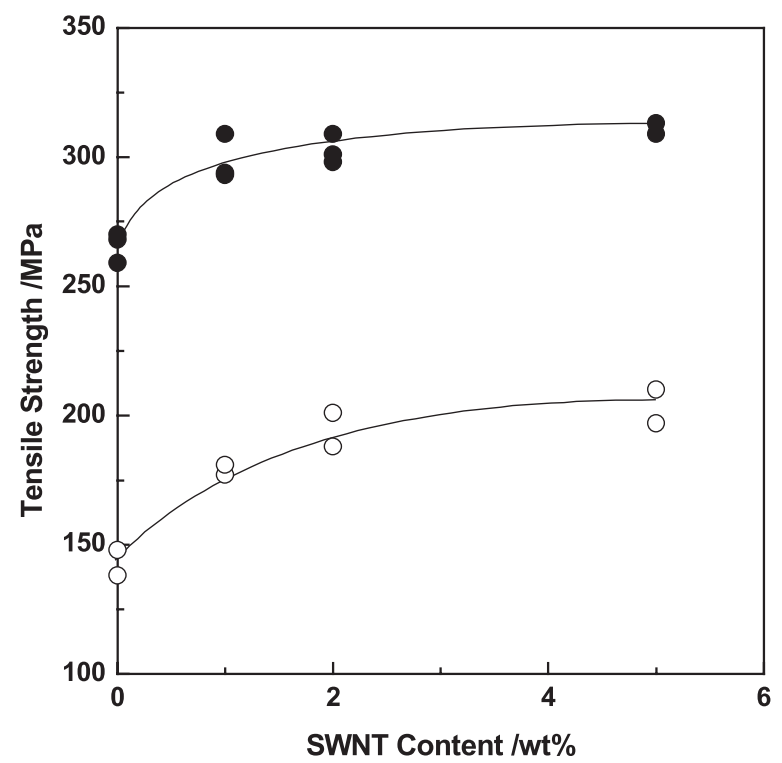

Fig. 10 Tensile strength vs. SWNT contents of PLLA/ SWNT composite films drawn by solid-state coextrusion at $T_{\mathrm{e}}=160^{\circ} \mathrm{C} ;(\bigcirc) \mathrm{EDR}=6$, $\mathrm{EDR}=9$. 
Table 1 Thermo-mechanical characteristics of PLLA/SWNT composite films and their drawn films

\begin{tabular}{|c|c|c|c|c|c|c|c|c|c|c|c|c|}
\hline & \multicolumn{4}{|c|}{ Cast Film } & \multicolumn{4}{|c|}{$\mathrm{EDR}=6$} & \multicolumn{4}{|c|}{ EDR $=9$} \\
\hline & $\begin{array}{c}E_{25}^{\prime a} \\
(\mathrm{GPa})\end{array}$ & $\begin{array}{l}E_{100}^{\prime}{ }^{b} \\
(\mathrm{GPa})\end{array}$ & $\frac{E_{100}^{\prime}}{E_{25}^{\prime}}$ & $\begin{array}{c}T_{\alpha} \\
\left({ }^{\circ} \mathrm{C}\right)\end{array}$ & $E_{25}^{\prime}$ & $E_{100}^{\prime}$ & $\frac{E_{100}^{\prime}}{E_{25}^{\prime}}$ & $T_{\alpha}$ & $E_{25}^{\prime}$ & $E_{100}^{\prime}$ & $\frac{E_{100}^{\prime}}{E_{25}^{\prime}}$ & $T_{0}$ \\
\hline PLLA-1 & 2.5 & 0.38 & 0.15 & 71 & 5.7 & 2.1 & 0.37 & 83 & 7.1 & 3.2 & 0.46 & 83 \\
\hline PLLA-2 & 2.7 & 0.48 & 0.18 & 73 & 6.5 & 2.7 & 0.42 & 83 & 7.4 & 3.4 & 0.46 & 83 \\
\hline PLLA-5 & 3.0 & 0.91 & 0.30 & 81 & 8.5 & 4.1 & 0.49 & 85 & 9.1 & 4.8 & 0.53 & 85 \\
\hline
\end{tabular}

a : Dynamic Young's modulus at $25^{\circ} \mathrm{C}$ measured at $11 \mathrm{~Hz}$.

b : Dynamic Young's modulus at $100{ }^{\circ} \mathrm{C}$ measured at $11 \mathrm{~Hz}$.

c : Peak temperature of loss modulus measured at $11 \mathrm{~Hz}$.

ほぼ一定であった。それにもかかわらず， $\Delta C_{\mathrm{p}}$ が SWNT 添加量の増加とともに顕著に減少したのは, 剛直非晶鎖 が存在しないと報告されている PLLA においても, SWNT によって分子鎖が拘束され, 剛直非晶鎖が形成され, そ の量は, SWNT 添加量の増加とともに増加したことを意 味する. 各試料の $T_{\mathrm{g}}$ における $\Delta C_{\mathrm{p}}$ から計算した剛直非 晶鎖の割合は，PLLA-0，PLLA-2 および PLLA-5において, それぞれ $0,0.17$ および 0.43 になる. SWNT 添加による このような剛直非晶鎖の生成は, SWNT が PLLA 内であ る程度ナノレベルで分散し, SWNT 近傍で SWNT-PLLA 間の強い相互作用が働いていることを示唆している。ま た, PLLA-0 および PLLA-5 試料を溶融急冷し, その後 DSC 測定をした結果, 結晶化に対応する発熱ピーク温度は, PLLA-5 試料において PLLA-0 試料より低温で, かつ シャープであったが，発熱量は，ほぼ同じであった。こ れらの事実は, SWNTが PLLAの核剤として作用し, 結 晶化速度を上昇させる役割があることを示している.

\section{3 延伸試料の物性}

SWNT は大きな異方性を有するため, コンポジットフィ ルム内で一軸方向に並べると飛躍的な物性の向上が期待 できる，そこで，延伸することによって SWNT を分子鎖 軸方向に配向させることによって，物性の向上を試みた， 延伸は固相共押出延伸によって行い, 全ての試料で延伸 が可能であった $T_{\mathrm{e}}=160^{\circ} \mathrm{C}$ において押出延伸倍率 (EDR) 6 および 9 に延伸をした。図 9 に延伸フィルムの引張弾性 率の SWNT 含有量依存性を示した.

延伸フィルムの弾性率は SWNT 含有率が増加するごと に増加した。延伸倍率によらず, 引張弾性率は SWNT 含 有量が増加によって直線的に増加し, $E D R=6$ では PLLA-0 で $5.2 \mathrm{GPa}$ であったのに対し, PLLA-5 では $8.5 \mathrm{GPa}$ となっ た。また， EDR=9では PLLA-0で 6 GPaであったのに対 し，PLLA-5では 9.2 GPa となった。 PLLA-5で達成され た最高到達引張弾性率は, PLLA-0を最適延伸条件 $\left(T_{\mathrm{e}}=170^{\circ} \mathrm{C}, \mathrm{EDR}=11\right)$ で延伸した試料の最高引張弾性率 (7.2 GPa)よりも高かった. SWNT 添加により, 延伸効率, 結晶性が変化し引張弾性率が変化している可能性がある ため, それらについて検討した，その結果，延伸によっ て結晶性および配向性は上昇したが，同一倍率における
結晶の配向性および結晶化度は, SWNT 添加量に無関係 にほぼ同じであることが分かったため, SWNT 添加によ る引張弾性率の上昇は, SWNT 添加による補強効果が主 であることがあきらかとなった。

図 10 に延伸フィルムの引張破断強度の SWNT 含有量依 存性を示した。延伸フィルムの破断強度は少量 $(1 \mathrm{wt} \%)$ の SWNT の添加で顕著に上昇し, その後 SWNT 添加量の上 昇ともに緩やかに上昇した。破断強度は $\mathrm{EDR}=6$ では PLLA-0 で $140 \mathrm{MPa}$ であったのに対し, PLLA-5 では 200 $\mathrm{MPa}$ となった. また, $\mathrm{EDR}=9$ ではPLLA-0 で $260 \mathrm{MPa}$ であったのに対し, PLLA-5 では $310 \mathrm{MPa}$ となった. SWNT を添加することにより，未延伸および $\mathrm{EDR}=6$ 試料では 引張弾性率と引張破断強度は SWNT 添加によって顕著に 向上した。しかし, $\mathrm{EDR}=9$ 試料においては, 引張弾性率 において SWNT 添加の効果が顕著に現れたが, 破断強度 の向上率は弾性率のそれと比較して低かった。このよう に $\mathrm{EDR}=9$ 試料において SWNT 添加による破断強度の上 昇率が低いのは，未延伸試料および $\mathrm{EDR}=6$ 試料では, 破断試験時の破断伸びが SWNT の有無によらず，ほぼ同 じであったのに対し, $\mathrm{EDR}=9$ 試料では SWNTを添加量 の増加に伴い, 破断伸びが低下しているためであった。

未延伸試料において, SWNT を添加したときの高温物 性が顕著に改善していたため, 同様の測定を延伸試料に おいても行った. それらの結果と Table 1 にまとめた. 比 較のために, 以前の研究で高い高温物性保持率を示した, ステレオコンプレックス結晶を有する PLLA/ポリ D 乳酸 (PDLA) 等量混合キャストフィルムの結果も載せた.

全ての試料で, 延伸倍率の上昇によって, 室温におけ る貯蔵弾性率, $100^{\circ} \mathrm{C}$ における貯蔵弾性率が高くなり, 主 分散ピーク温度が高温にシフトしていることが分かった。 また，同一のフィルム作製条件では，SWNT 添加量が多 い試料ほど常にそれらの值は高く, $100^{\circ} \mathrm{C}$ における物性保 持率も高かった. PLLA-5 未延伸試料で得られた $100^{\circ} \mathrm{C} に$ おける物性保持率 (0.30) は, 以前に PLLA/PDLA キャスト フィルムで報告した物性保持率 $(0.27)$ よりも若干高く, $100^{\circ} \mathrm{C}$ における貯蔵弾性率は 1.6 倍程度を有していた $[5]$. このように, 試料の物性は SWNT 添加量および延伸倍率 によって顕著に異なった。 それ故, コンポジット試料内 でのSWNT の分散状態, 延伸に伴うSWNT の分散状態お 
よび配向の変化を理解することが, それらの物性発現入 カニズムを知る上で重要であると考えられる。これらの 分散状態および構造評価にたい寸る詳細は次報で報告予 定である.

\section{4. 結 論}

分散状態の良好な PLLA/SWNT コンポジットフィルム の作製条件を検討し，ついで作製したそれらのフィルム の物性と構造を引張試験, DSC 測定, 粘弾性測定により 検討した。作製フィルムにおける SWNT の分散状態は, 溶媒種, ポリマー濃度に顕著に依存した。最も良好な分 散状態を有する PLLA/SWNT コンポジットフィルムは, $5 \mathrm{wt} \%$ クロロホルム溶液から得られた. SWNT 添加量の増 加とともに, コンポジットフィルムの引張弾性率, 引張 強度は上昇することが分かった．粘弾性測定を行った結 果, SWNT 添加量の増加とともに, 主分散ピーク温度が 高温側にシフトするため高温における貯蔵弾性率が顕著 に高くなり，耐熱性が大きく改善されることが分かった。 $5 \mathrm{wt} \%$ の SWN を添加したPLLA-5 試料では, 無添加の PLLA- 0 試料と比較して, 主分散ピーク温度が $14^{\circ} \mathrm{C}$ 高温 にシフトし, $100^{\circ} \mathrm{C}$ における貯蔵弾性率が 3.3 倍となった. これらの原因について検討した結果，DSC 測定によって， PLLA 剛直非晶鎖の増大が示唆された. PLLA/SWNT コン ポジットフィルムを延伸し引張弾性率を測定した結果, PLLA-5 試料を $T_{\mathrm{e}}=160^{\circ} \mathrm{C}, \mathrm{EDR}=9$ まで延伸した試料は, PLLA-0 試料を最適延伸条件で延伸した試料 $\left(T_{\mathrm{e}}=170^{\circ} \mathrm{C}\right.$, $\mathrm{EDR}=12)$ よりも高い值を示した $(9.2 \mathrm{GPa}$ vs $7.2 \mathrm{GPa})$.こ のように, SWNT 添加試料を延伸することによって, 優 れた耐熱性, 力学特性を有する材料が作製できることが 分かった.

謝辞 本研究は, NEDO 技術開発機構平成 17 年度産業技 術研究助成事業の助成 (05A52002c) により行われました. 助成に深 $<$ 感謝致します.

\section{文 献}

1. D. Sawai, K. Takahasi. T. Imamura, K. Nakamura, T. Kanamoto, S. H. Hyon, J. Polym. Sci., Polym. Phys. Ed, 40, 95 (2002).

2. D. Sawai, K. Takahashi, A. Sasashige, T. Kanamoto, S. H. Hyon, Macromolecules, 36, 3601 (2003).

3. K. Takahashi, D. Sawai, T. Yokoyama, T. Kanamoto, S. H. Hyon, Polymer, 45, 4969 (2004).

4. D. Sawai, T. Yokoyama, T. Kanamoto, M. Sungil, S-H.
Hyon, L. P. Myasnikova, Macromol. Symp., in press.

5. D. Sawai, M. Tamada, T. Yokoyama, T. Kanamoto, S-H. Hyon, S. Moon, submitted to SEN'I GAKKAISHI

6. T. Miyata, T. Masuko, Polymer, 39, 5515 (1998).

7. M. L. D. Lorenzo, Polymer, 42, 9441 (2001).

8. Y. Ohtani, K. Okamura, A. Kawaguchi, J. Macromol. Sci., Part B, B42, 875 (2003).

9. H. Yamane, K. Sasai, Polymer, 44, 2569 (2003).

10. K. Inoue, S. Serizawa, M. Iji, NEC Technical Journal, 57, 77 (2004).

11. H. Iwasaki, T. Inao Japan Patent Publication Number 2004-284246, Japan (2004).

12. Y. Miyamoto, Kobunshi, 54, 747 (2005).

13. M. Pluta, Polymer, 45, 8239 (2004).

14. J-H. Chang, Y. U. An, D. Cho, E. P. Giannelis, Polymer, 44, 3715 (2003).

15. S. S. Ray, P. Maiti, M. Okamoto, K. Yamada, K. Ueda, Macromolecules, 35, 3104 (2002).

16. G-X. Chen, H-S. Kim, J-H. Shim, J-S. Yoon, Macromolecules, 38, 3738 (2005).

17. N. Ogata, G. Jimenez, H. Kawai, T. Ogihara, J. Polym. Sci., Polym. Phys. Ed., 35, 389 (1997).

18. S. Moon, F. Jin, C-J. Lee, S. Tsutsumi, S-H. Hyon, Macromol. Symp., 224, 287 (2005).

19. M. Moniruzzaman, K. I. Winey, Macromolecules, 39, 5194 (2006).

20. H.G. Chae, T. V. Sreekumar, T. Uchida, S. Kumar, Polymer, 46, 10925 (2005).

21. Y. Inoue, "Recent Advances in Research and Development for Green Plastics", CMC, Tokyo (2002).

22. H. Okamoto et al., Japan Patent Publication Number 2005060474, Japan (2005).

23. I. W. Chiang, B. E. Brinson, A. Y. Huang, P. A. Willis, M. J. Bronikowski, J. L. Margrave, R. E. Smalley, R. H. Hauge, J. Phys. Chem. B , 105, 8297 (2001).

24. J. Enta, D. Sawai, T. Kanamoto, M. Ito, SEN'I GAKKAISHI, 58, 262 (2002).

25. J. Grebowica, S-F. Lau, B. Wunderlich, J. Polym. Sci., Polym. Symp., 71, 19 (1984).

26. S. Z. D. Cheng, M-Y. Gao, B. Wundelich, Macromolecules, 19, 1868 (1986).

27. H. Xu, B. S. Inge, P. Cebe, J. Polym. Sci., Polym. Phys. Ed., 41, 3026 (2003).

28. M. Pyda, R. C. Bopp, B. Wunderlich, J. Chem. Thermodynamics, 36, 731 (2004). 